\title{
IUBIREA JUVENILĂ ÎN LUMINA IUBIRII TRINITARE
}

\author{
Bucea Petru Sorin*
}

Abstract: Youthful Love in the Light of the Trinitarian Love. Youth is that period of life which influences the most our way and events along the time. For this reason it gets most of attention both from young and old people.

The aim of this research is to propose a divine-human analysis of the feelings of love from the young period. Love seems to be compound of several parts which are complementary and symbiotic, not at all exclusivists: the experience: physical, psychic, rational and spiritual. And for love to become fully, overwhelming and useful it is required to be combined with the true love of God.

Keywords: youth, love, God, love of God, divine-human relation.

\section{Prolog}

Este unanim acceptat faptul că tinereţea înseamnă perioada reuşitelor, marcată de mult curaj şi forţă fizică. Şi cum una dintre preocupările de baze ale oricărui om este grija de mâine, tot ceea ce se face în această perioadă se doreşte să aibă repercusiuni cât mai îndelungate în timp, dacă se poate, pe durata întregii vieţi.

Consider că bazele unei vieţi confortabile, dar în acelaşi timp şi morale, se pun în tinereţe. Cu toate că în tradiţia populară se spune că: dacă tinereţea ar şti şi bătrâneţea ar putea, totuşi cred că înţelepciunea nu vine de la sine odată cu trecerea timpului. Nivelul înţelepciunii creşte direct proporţional cu puterea de asimilare a situaţiilor cotidiene şi implicit cu gradul de experienţă format.

Pornind de la aceste premise, consider că un sens şi o finalitate a lucrurilor făcute în tinerețe e necesar să fie dat atât de către capacitatea şi forţele umane dar şi de un factor extern, un factor care se cere a fi el însuşi veşnic. Acest factor nu poate să fie decât un

\footnotetext{
* PhD candidate, Faculty of Orthodox Teology, at "1 Decembrie 1918" University, Alba Iulia, Romania.
} 
Principiu Absolut şi Creator, în cazul de faţă Dumnezeu Cel în Treime închinat. Se întrevede aşadar o cercetare care îşi propune să realizeze o analiză a iubirii şi a sensului iubirii tinereşti în prisma iubirii depline din cadrul Dumnezeului tripersonal.

Astfel, aceste subiecte au fost larg dezbătute şi mereu actualizate la necesităţile vremii. Tinereţea a constituit punct de interes pentru cercetători din domenii variate: psihologie, sociologie, medicină, filosofie, teologie etc. Sfânta Treime a fost subiect de mari sondări teologice de la începuturile creştinismului şi până astăzi.

Pentru studiul de faţă au fost de un real folos câteva lucrări consacrate ale Părintelui Stăniloae. Sfânta Treime a constituit un subiect de mare interes pentru părintele Stăniloae, remarcându-se nu doar prin faptul că a explicat paradoxala dogmă într-un mod extrem de complex şi argumentat, ci, şi prin faptul că a oferit dovezi clare şi practice ale înţelegerii acesteia. Amintim lucrările: Sfânta Treime structura supremei iubiri. O altă lucrare esenţială, este cea a îndrumătorului meu de doctorat, domnul Daniel Munteanu, Pe urmele iubirii - contribuţii trinitare la o cultură comunicării sfinţitoare. O lucrare caracterizată de fundamentări biblice şi patristice. $\mathrm{Cu}$ toate că păstrează duhul ortodox în întregime, lucrarea este impregnată şi de un larg spirit ecumenic şi practic. Amintim iarăşi un articol al părintelui Sabatie Baştovoi, care a scris într-un mod sublim şi pe înţelesul fiecăruia despre Taina iubirii: Teama de a vorbi celui iubit.

\section{Sfânta Treime în viaţa omului}

Experienţa treimică este o experienţă cotidiană care îşi are obârşia în Dumnezeu Tatăl, manifestarea în Dumnezeu Fiul, comunicarea în Dumnezeu Duhul Sfânt. Astfel, putem descrie învăţătura despre Sfânta Treime ca matrice care trebuie să influenţeze în mod hotărâtor întreaga gândire creștină ${ }^{1}$. Omul este

${ }^{1}$ Daniel Munteanu, Pe urmele iubirii - contribuţii trinitare la o cultură a comunităţii sfinţitoare, Târgovişte, Edit. Bibliotheca, 2013, p. 36. 
creat după chipul Treimii dumnezeieşti. Există un eu-tu-el, o fiinţă în comuniune cu Dumnzeu şi cu creaturile. Astfel, comuniunea eclezială revelează misterul comuniunii treimice ca bază, modul şi scopul ultim al Bisericii şi invers, comuniunea Treimică fundamentează, structurează şi explică misterul comuniunii ecleziale $^{2}$.

Biserica Ortodoxă vede Sfânta Treime, ca Dumnezeul iubirii lucrătoare prin Duhul Sfânt în sufletele credincioşilor, pentru a-i ridica în relaţia iubitoare dintre Persoanele Ei. De iubire nu se satură nimeni (iubirea $n u$ satură pe nimeni niciodată) ${ }^{3}$. Iubirea dintre Persoanele Sfintei Treimi a precedat creaţia, şi tot ea este cea care a motivat aducerea la fiinţă din nimic a lumii şi a omului, cea care a dat lui Dumnezeu acest Să facem. Dacă Treime nu e, Iubire nu $e^{4}$. Deci: există fiinţă, există lumea şi omul pentru că există Sfânta Treime.

La temelia acestei lumi, a intregii existenţe văzute care se arată tot mai zdruncinată, incercată şi dezbinată stă, aşadar, o iubire veşnică, de neclintit, desăvârşită, atotputernică şi singură mântuitoare, cea a Prea Sfintei Treimi ${ }^{5}$. Însă cunoaşterea lui Dumnezeu ca Treime nu e numai fundamental, ci şi scopul suprem al teologiei.

Sfânta Treime nu este o invenţie a umanităţii, sau a unei părţi a umanităţii (n.n. noi, creştinii) ci este adevărul descoperit de Dumnezeu pentru umanitate, pentru ca omenirea să-şi dea seama de existenţa intercomunională din sânul Sfintei Treimi, şi astfel să ajungă şi toate persoanele umanităţii (pentru că toţi suntem persoane libere) prin iubire, la o astfel de comuniune.

\footnotetext{
${ }^{2}$ Nifon Ploieşteanul, Sfânta Treime şi comuniunea, în „Ortodoxia”, nr. 3, iulieseptembrie, 2005, p. 3

${ }^{3}$ Dumitru Stăniloae, Sfânta Treime sau la început a fost iubirea, Bucureşti, Edit. Institutului Biblic și de Misiune al Bisericii Ortodoxe Române, 2005, p. 8.

${ }^{4}$ George Remete, Fiinţa şi credinţa, vol. 1: Ideea de fiinţă Bucureşti, Edit. Academiei Române, 2012, p. 393.

${ }^{5}$ Dumitru Stăniloae, op. cit., p. 6.
} 
Cunoaşterea lui Dumnezeu ca Treime nu înseamnă doar însuşirea unor învăţături, (dogme) definiţii, care-L descoperă ca Monadă şi Triadă în acelaşi timp, ci şi trăire duhovnicească curată, unire mistică care duce la sfinţirea şi trăirea Dumnezeului întreit ipostatic $^{6}$. Treimea fiinţială şi Treimea iconomică trebuie să se dizolve una în alta ${ }^{7}$. Intrucât în dinamică Iconomiei divine ad extra, comuniunea treimică se comunică credincioşilor în mişcarea desecendentă a harului sau energiilor divine: de la Tatăl, prin Fiul, în Duhul Sfânt ${ }^{8}$.

O înţelegere adecvată a creştinismului presupune nu numai acceptarea şi mărturisirea doctrinei despre Treime, ci şi transpunerea ei în practică, în cult şi într-un mod de viaţă trinitară.

Învăţătura despre Sfânta Treime are o importanţă deosebită pentru viaţa duhovnicească a credincioşilor. Căci aşa cum Persoanele Sfintei Treimi există una în alta şi din alta, într-o unitatefiinţială (triada homoousion), tot aşa creştinii formează o unitate şi o comuniune de credinţă, nădejde şi iubire în Dumnezeu. Creştinul participă prin har la viaţa Sfintei Treimi: În ziua aceea veţi cunoşte că Eu sunt în Tatăl Meu şi voi în Mine şi Eu în voi (In. 14, 20). Biserica este un popor al lui Dumnezeu şi o comuniune de viaţă după chipul Sfintei Treimi ${ }^{9}$. În raport cu gradul de credinţă, fiecare creştin pătrunde în Hristos. Această inhabitare înseamnă în acelaşi timp implinirea dorului omului şi întoarcerea la comuniunea cu originea existenţei. Prin aceasta omul face experienţa unei odihne dinamice in Dumnezeu ca 'anticipare a desăvârşirii fiinţei sale ${ }^{10}$.

\footnotetext{
${ }^{6}$ Mihai Himcinschi, Doctrina trinitară ca fundament misionar, Relaţia Duhului Sfânt cu Tatăl şi cu Fiul în teologia răsăriteană şi apuseană. Implicaţiile doctrinare şi spirituale ale acesteia, Alba Iulia, Edit. Reîntregirea, 2004, p. 55. ${ }^{7}$ Karl Christian Felmy, Dogmatica experienţei ecleziale, înnoirea teologiei ortodoxe contemporane, Sibiu, Edit. Deisis, 1999, p. 84.

${ }^{8}$ Nifon Ploieşteanul, art. cit., p. 3

${ }^{9}$ Ion Bria, Dogma Sfintei Treimi, în „Studii Teologice”, seria a II-a, anul XLIII, nr. 3, mai-iunie, 1991, p. 47.

${ }^{10}$ S. Maximi Confessoris, Questiones ad Thalasium, PG 90, p. 608, apud Daniel Munteanu, op. cit., p. 42.
} 
In extremis a crede în Treime înseamnă a crede în autenticitatea, deplinătatea şi şansa absolută a omului, înseamnă a crede în $\mathrm{om}^{11}$.

Aşadar, gândirea Treimii în categoria comuniunii are o relevanţă pentru societate. Omul poate să se orienteze pe baza comuniunii treimice şi să-şi organizeze viaţa într-un mod corespunzător acesteia ${ }^{12}$.

„Precum în Sfânta Treime o persoană face loc celorlalte două, la fel trebuie şi omul să se retragă, să fie gata de jerftă. O viaţă umană care se orientează după chipul Dumnezeului treimic este marcată de o sensibilitate adâncă. Creştinul înțelege libertatea sa ca iubire chenotică şi iubirea sa chenotică drept libertate în comuniunea Dumnezeului trinitar"13.

\section{Perihoreza trinitară - model de viețuire umană}

Prin conceptul de perihoresis sau circumincensio a persoanelor trinitare se arată mişcarea circulară a vieţii dumnezeieşti veşnice ${ }^{14}$. Dinamica întrepătrunderii reciproce poate fi prezentată ca dinamică a inhabitării reciproce ${ }^{15}$.

Sfântul Ioan Damaschin arată pentru prima dată clar raportul de intersubiectivitate dintre persoanele Sfintei Treimi prin termenul perihoreză. Legătura dintre trinitatea şi unitatea de fiinţă, în Dumnezeu, în baza întrepătrunderii şi a enipostaziei este perihoreza ${ }^{16}$.

Cele trei ipostase în care subzistă fiinţa divină au nu numai realitatea lor subiectivă, distinctă, ci şi interpersonalitatea sau

\footnotetext{
${ }^{11}$ George Remete, op. cit., p. 394.

${ }^{12}$ Daniel Munteanu, op. cit., p. 75.

${ }_{14}^{13}$ Ibidem, p. 76.

14 Jurgen Moltmann, Treimea şi Împărăţia lui Dumnezeu, Alba Iulia, Edit. Reîntregirea, 2007, p. 222.

${ }^{15}$ Daniel, Munteanu, op. cit., p. 35-36.

16 Vasile Loichiţa, Perihoreza si enipostasia în Dogmatică, în „Ortodoxia”, anul X, nr. 1, ianuarie-martie, 1958, p. 8.
} 
intersubiectivitatea lor personală. În sânul Treimii există o perihoreză, o mişcare interpersonală, o comuniune perfectă fără amestecarea ipostasurilor, având un singur principiu.

„Concepţia perihoretică, profund biblică (In. 10, 30; 14,11; 16, 32; 17, 21 ; etc.), depăşeşte orice idee de confuzie a persoanelor prin comuniune, sau de sfâşiere a esenţei divine prin distincţiile personale. De aceeaşi fire, persoanele 'sunt unele în celelalte, dar nu în sensul că se confundă, ci în sensul că sunt unite', întrepătrunderea reciprocă a ipostasurilor fiind fără contractare şi fără amestec. Pe scurt: ipostasurile sunt unite fără confuzie şi distincte fără separaţie, ceea ce pare şi absurd" ${ }^{17}$.

Scopul vieţii este îndumnezeirea, cunoaşterea lui Dumnezeu sau mântuirea. Ori cunoaşterea lui Dumnezeu trebuie să fie una personală dar şi reală, în sensul de a-L cunoaşte pe El aşa cum este. Nu putem vorbi de vreo dependenţă a Treimii față de fiinţele create, nu există nici o determinare a ceea ce se numeşte 'purcederea veşnică a persoanelor dumnezeieşti prin actul facerii lumii. S-ar putea ca făpturile să nu existe şi totuşi Dumnezeu ar fi Treime - Tată, Fiu şi Duh Sfânt, căci creaţia este un act de voinţă, iar purcederea persoanelor este un act după fire. Gândirea trebuie să fie mereu în mişcare şi să alerge neîncetat când la unul, când la Cei Trei spre a reveni apoi la unitate; ea trebuie să se împartă neîncetat între cei doi termini ai antinomiei spre a ajunge la vederea lăcaşului Celui Preaînalt al acestei monade în trei ${ }^{18}$.

Acest mod de unitate supremă a lui Dumnezeu este şi scopul nostru ca persoane, adică unitatea în iubire, cea mai perfectă şi mai plină de sens unitate. Astfel, omul ca fiinţă însetată de Dumnezeu împlinirea umanului constă în canalizarea dorului către Dumnezeu, adică de a iubi pe Dumnezeu cu toată puterea, cu toată pasiunea, de

${ }^{17}$ Sfântul Ioan Damschin, Dogmatica, I, 8, apud Dumitru Popescu şi Doru Costache, Introducere în Teologia Dogmatică, Bucureşti, Edit. Libra, 1997, p. 77.

${ }^{18}$ Vladimir Lossky, Teologia mistică a Bisericii de Răsărit, Bucureşti, Edit. Bonifaciu, 1998, p. 43. 
a-1 reţine pe Dumnezeu în interiorul său, de a rămâne mereu în comuniune cu Duhul Sfânt prin rugăciune şi iubire ${ }^{19}$.

Privitor la criza actuală din lume, luând ca model Sfânta Treime învăţam să ne raportăm, cu iubire unul la celălalt, pentru că lucrurile au rostul demonstrării iubirii dintre persoane. Orice iubire între persoane se manifestă în dăruire; bucuria ta vine din capacitatea altuia de a renunţa la el pentru tine, dar şi din capacitatea ta de a-1 putea da altuia.

Dăruirea dusă la superlativ reprezintă dăruirea proprei persoane. Acest lucru putându-se realiza doar la Dumnezeu $o$ persoană divină se dăruieşte în iubirea sa supremă alteia.

Dar dăruirea e şi reciprocă (şi între persoanele divine). De exemplu: un tată care îl iubeşte pe fiul său, se simte împlinit atunci când fiul ăi răspunde cu aceeaşi dragoste Ceea ce hrăneşte existenţa fiecăruia este în fond iubirea altuia. Existenţa fără iubire nu constituie în ea însăşi o bucurie $e^{20}$.

În unitatea intratreimică persoana nu rămâne în izolare ci este deschisă spre comuniune. Este cert că în cadrul unităţii intratreimice vorbim de o iubire deplină a persoanelor. Iar în această iubire deplină, persoanele nu se dăruiesc numai reciproc şi nu se acceptă numai, ci se şi afirmă, se pun în existenţă prin dăruire reciprocă.

Şi în această dăruire reciprocă este valorificat la maxim specificul fiecărei persoane şi anume o persoană divină dăruieşte în iubirea sa supremă alteia, fără să se poată pierde.

$\mathrm{Cu}$ toate acestea, putem vorbi chiar de o omousianitate umană. Aceeaşi sursă manifestată şi în mine şi în tine şi în el... Însă totuşi noi suntem diferiţi, ne completăm reciproc, ceea ce nu se întâmpla cu persoanele divine, separaţia nefiind totală sau ontologică. În cazul oamenilor ousia e repetabilă. În schimb la Dumnezeu nu se întâmplă acest lucru. La Dumnezeu, firea e posedată în modul comun total.

\footnotetext{
19 Gregoire Palama, Defense des saints hesychastes, p. 370, apud Daniel Munteanu, op. cit., p. 251.

${ }^{20}$ Ibidem, p. 338; însă fiecare parte îşi păstrează poziţia proprie.
} 
Când vorbim, însă despre deofiinţimea umană trebuie să ştim că aceasta nu constă numai în identitatea unei naturi posedate de persoane distanţate ci într-o unică fiinţă purtată de toate ipostasurile într-o solidaritate, deşi unele persoane se mântuiesc covârşite de Duhul lui Hristos, altele nu ${ }^{21}$.

Deasemenea trebuie să ştim că, în cazul oamenilor, fiinţa apare asemenea unui fir de aţă, iar oamenii reprezintă nodurile de pe acest $\operatorname{fir}^{22} . \mathrm{Cu}$ alte cuvinte oamenii au aceeaşi fiinţă divină dar observăm că între ei intervine îngustarea. Pentru că logic vorbind, nodurile sunt mult mai groase decât firul de aţă, deci observăm aici raportul dintre ipostasul uman şi fiinţa umană, care se transmite din om în om, din persoană în persoană, dar aceasta nu e întreagă, nu e desăvârşită, tocmai datorită acestei întreruperi sau subţieri, de care vorbeam, între aceste noduri. Tot referitor la ipostasul uman, putem afirma că înainte de cădere, omul era ipostas deplin al întregii creaţii, dar după cădere, prin instalarea afectelor, omul a ajuns o existenţă individuală egoistă. Ori de aici porneşte căutarea întoarcerii înapoi ${ }^{23}$ a omului, dar nu doar la starea de dinainte de cădere, la starea paradisiacă, ci la cea de mântuire, pentru că în Hristos harul se revarsă ca har peste har.

\section{Tânărul şi iubirea}

În capitolele anterioare observat faptul că există relaţii clare de iubire între Dumneu si om pe de o parte, între Persoanele Sfintei Treimi; si între toţi oamenii pe de altă parte.

$\mathrm{Cu}$ alte cuvinte, relaţia si relaţionarea este secretul vieţii în comuniune, comuniune care se realizează şi între generaţii. atitudini:

Astfel, în raportul cu tinerii se afişează de obicei două

${ }^{21}$ Dumitru Staniloae, Teologie Dogmatică Ortodoxă, vol. I, București, Edit. Institutului Biblic şi de Misiune al Bisericii Ortodoxe Române, 1996, p. 202.

${ }^{22}$ Ibidem, p. 196.

${ }^{23}$ Vezi Slujba de la înmormântare. 
a. Una ostilă, constituită sub forma unei mime scandalizate, o atitudine în care se exagerează gravitatea faptelor

b. Una de maximă toleranţă, prin care se doreşte o asemănare cât mai perfectă cu modul de vieţuire al tinerilor.

Ambele atitudini se văd a fi situate la extremă, şi din această cauză sunt şi deficitare şi implicit nerodnice.

Tânărul caută să creeze ceva propriu, original, diferit şi indepent de tot ceea ce înseamnă clasic şi social. Acest lucru nu poate fi unul rău. Totuşi, individualitatea persoanei este condiţionată de o anumită păstrare a nivelului de comuniune şi de apartenenţă. $\mathrm{O}$ comuniune bidirecţionată:

a. Pe vector orizontal - în acest sens importante sunt relaţiile închegate în cadrul familiei, al grupului de prieteni, al grupului colegial, al comunităţii în care trăieşti, aşadar relaţia cu semenii

b. Pe vector vertical - iar în acest sens importantă şi la fel de necesară este o relaţie cu o Persoană - asemenea nouă dar în acelaşi timp diferită - în acest caz Dumnezeul tripersonal, Cel de departe şi în acelaşi timp Cel din jurul şi împrejurul nostru.

Relaţia cu ceilalţi este indicatorul stării sale şi al adevăratei lui relaţii cu Dumnezeu. Aceasta întrucât: Dacă zice cineva: iubesc pe Dumnezeu, iar pe fratele său îl urăşte, mincinos este! Pentru că cel ce nu iubeşte pe fratele său, pe care l-a văzut, pe Dumnezeu, pe Care nu L-a văzut, nu poate să-L iubească (I In. 4, 8).

\section{1. Curajul de a iubi}

Este lesne de observat, în cercurile de prieteni ale fiecăruia dintre noi, faptul că exista o imensă teamă de a-ţi împărtăşi iubirea. cei mai mulţi tineri prefer să se dea în spatele unor autorităţi consecrate. Un tânăr va suferi mai uşor eşecul unui început de relaţie, dacă acest eşec va fi provocat de un bileţel care conţinea un vers de Eminescu sau o maximă a unui guru indian ${ }^{24}$. Întrebarea

${ }^{24}$ Savatie Baştovoi, Teama de a vorbi celui iubit, în „Orthografiti”, anul IV, nr. 17, ianuarie 2011, p. 8. 
inerentă este: cum e posibil să te laşi pe mâna unui om care se pricepe la cuvinte să-ţi redacteze gânduri de dragoste către persoana iubită, şi să nu ai curajul de a-ţi asuma responsabilitatea de a fi tu însuţi în faţa dragostei.

Părintele Savatie Baştovoi a fost rugat de mai multe ori să scrie scrisori de dragoste, în numele unui cutare tânăr către iubita sa, pe care Ieromonahul nici măcar nu o cunoştea. Iar răspunsul părintelui este sublim: Desigur, n-am scris niciodată astfel de scrisori. $N$-am scris pentru că niciodată n-am inţeles cum cineva care iubeşte nu poate găsi cuvinte pe care să le spună celui iubit ${ }^{25}$.

A vorbi despre dragoste, fără să o simţi, este ca şi cum vorbeşti despre Dumnezeu, fără a-I simţi prezenţa. Dragostea nu are nevoie de purtători de cuvânt. Iar cea mai deplină declaraţie de dragoste este prezenţa şi îmbrăţişarea ${ }^{26}$. În atare condiţii putem afirma că un cuvânt îşi realizează menirea pentru care a fost emis doar în măsura în care emiţ̧ătorul este el însuşi în acel cuvânt.

„Hristos ne-a arătat că ne iubeşte nu pentru că ne-a vorbit frumos, şi
îndrăznesc să spun, nici măcar pentru că a murit pentru noi, ci, mai
ales, pentru că ne-a încredinţat că El însuşi este cu noi până la sfârşitul
veacului. S-ar fi putut întâmpla ca Cel ce a murit pentru noi cu 2000
de ani în urmă, să-şi schimbe relaţia faţă de omenire acum sau mâine,
după cum mulţi îndrăgostiţi, care au făcut gesturi de jertfă, s-au
schimbat în timp"27.

Este lesne de înţeles cum prezenţa este dovada cea mai deplină de iubire. Dorinţa şi fapta de a fi prezent lângă cel iubit întreaga viaţă semnifică un bun început al veşnicei prezente în iubirea perfectă a Sfintei Treimi ${ }^{28}$.

${ }^{25}$ Ibidem.

${ }^{26} \mathrm{ftp}: / / \mathrm{ftp} . \log 0 \mathrm{~s} . \mathrm{md} /$ Biblioteca/_Colectie_RO/Dumitru_Staniloae_Comunitate prin iubire.pdf. (accesat la data de 13.04. 2016)

${ }^{27}$ Savatie Baştovoi, art. cit., p. 8.

${ }^{28} \mathrm{O}$ prezenţă care cred ca e necesar să fie în doi. Cu toate că ştim ca atunci „când vor invia din morti, nici nu se mai insoara, nici nu se mai marita, ci sunt ca ingerii in ceruri" - spune Mantuitorul Hristos - (cf. Mc. 12, 25; cf. Mt. 22, 
Atât cuvintele, cât şi faptele noastre, au o valorare numai în măsura în care pot rămâne veşnice, veşnicie pe care o primesc doar în perspectiva impregnării lor în Principiul Unic Veşnic, Dumnezeu.

Prezența cuiva înseamnă golirea a ceva, golirea egoismului intern. Această golire este necesară în omul căzut, om căzut datorită egoismului acceptat şi însuşit în Grădina Edenului.

\section{2. Prietenie şi dragoste}

Prietenia este singura relaţie care nu a primit o instituţionalizare şi nici măcar Biserica nu i-a materializat inefabilitatea printr-o Taină sau ierurgie ${ }^{29}$.

Prietenia nu se împarte. Posibil ca tu să ai o constelaţie de prieteni, şi toţi să se bucure de tine ca întreg. Prietenia rămâne mereu întreagă pentru fiecare prieten, ea nu se divide niciodată.

Printre încercările de caracterizare a prieteniei se văd mai multe definiţii: unii o văd undeva sub dragoste, alţii îi văd importanţa în eficienţa întrajutorări reciproce. Însă, sintetizând, prietenia este împreună trăirea suferinței şi a bucuriei, acea perihoreza umană mistica care te determină fiinţial să simţi stările prietenului tău.

Şi prietenia dă sens vieţii, ştii că faci bine ceea ce faci atunci când eşti prieten de nădejde pentru cel de lângă tine.

30; Lc. 20, 35-36), mă văd nevoit să îmi prezint punctul de vedere. Făcând o extrapolare logică, vedem că nici un sentiment uman nu este resimţit decât în prisma raţiunii. Altfel nu am fi în stare să deosebim nici măcar iubirea (sentimentul primordial al creaţiei). Aşadar, cel puţin în primsa gândirii umane limitate, şi apelând la principiul silogismului, cred că şi în viaţa veşnică e necesară o raţiune pentru a simţi sentimenul de prezenţă/lipsă a lui Dumnezeu, corespunzător stării de fericire respective stării de tristeţe. Astfel, se cere ca raţiunea (facultate proprie omului, de a cunoaște prin noțiuni, judecăți, raționamente; gândire-logică) să fie veşnică. În acest caz este de dorit ca starea de fericire a Raiului să fie trăită cel puţin alături de soţul sau soţia din viaţa de aici.

${ }^{29}$ Costion Nicolescu, Miza pe prietenie, în „Orthografiti”, anul 1, nr. 2, decembrie, 2008, p. 6. 


\section{Epilog}

Este necesar ca totalitatea acţiunilor pe care le întreprindem să aibă o finalitate. Această finalitate nu poate să fie cea dorită, dacă începutul nu este unul bun.

Astfel, consider de o reală necesitate acţiunea fiecăruia de a se gândi la rolul şi la sensul său pe pământ. În acest sens afirmă şi Sfântul Paisie: Cel care nu se gândeşte, nu se nelinişste pentru aflarea rostului sau da dovadă de om indiferent ${ }^{30}$.

Sigur că este mult mai uşor să primeşti acest sens şi rost din exterior, fără nici un aport al tău. În acest sens se cade în două extreme:

a. Atitudinea în care responsabilitatea ta este dominantă în a-ţi da sens propriei tale vieţi singur, fără absolut nici un ajutor extern.

b. Atitudinea de pasivitate extremă în care tronează ideea ca ceva sau chiar Cineva îţi va aranja lucruruile, fără nici o acţiunea proprie.

Este vreuna dintre cele două atitudini cea corectă? Afirmăm că nu. Ca de multe ori, creştinismul în general, şi Ortodoxia în special, găseşte aurea mediocritas. În acest caz, această echilibrare a celor două atiudini se realizează printr-o simbioză şi conlucrare a harului dumnezeiesc şi a libertăţii umane.

Conchidem aşadar, afirmând că atât omul cât şi cosmosul sunt create pentru a fi părtaşi la comuniunea iubirii Sfintei Treim ${ }^{31}$.

Anexez şi explicaţia principalelor verbe folosite în limba greacă, pentru a exprima sentimentele de iubire/afecţiune.

Astfel:

1. $\dot{\alpha} \gamma \alpha \pi \alpha ́ \omega$

${ }^{30}$ Cuviosul Paisie Aghioritul, Cuvinte duhovniceşti, vol. II: Viaţa de familie, trad. de Ştefan Nuţescu, Bucureşti, Edit. Evanghelismos, 2003, p. 33.

${ }^{31}$ Daniel Munteanu, op. cit., p. 273. 
Se întâlnește la Homer cu sensul a primi cu afecțiune pe

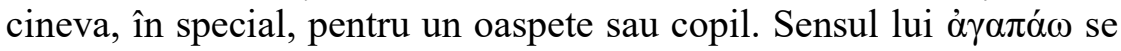
apropie destul de mult de cel al lui $\varphi \imath \lambda \dot{\varepsilon} \omega$, însă este mult mai expresiv. Se întâlnește în Evanghelia după Marcu și ca formă de salut

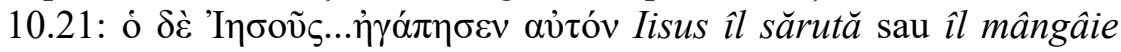
sau, după alții, a prins drag de el.

$\mathrm{Cu}$ acest verb se poate exprima afecțiunea față de animale cu sensul de a mângâia, dragostea dintr-o pereche: $\mu \tilde{\alpha} \lambda \lambda \mathrm{ov}$ iे $\Lambda \varepsilon ı \alpha$ LXX Gen.29.30 a iubit-o mai mult pe Rahila decât pe Lia, dragostea dintre rude, dragostea ca sentiment îndreptat către

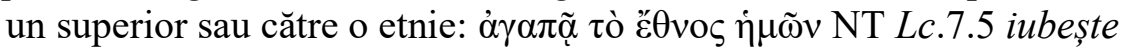
neamul nostru.

În sens religios, prin acest verb anticii își exprimau iubirea față de morți, prin aducerea de onoruri. La Euripide se întâlnește

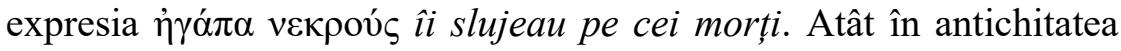
păgână, cât și în creștinism, prin acest verb se exprima iubirea divinității față de om și invers.

Pentru iubirea față de lucruri și abstracțiuni are sensul de a-i conveni; a se mulțumi (cu ceva); a-i plăcea; a fi împătimit (după ceva).

2. $\varphi \imath \lambda \varepsilon ́ \omega$

1. a iubi, a trata cu afecțiune, exprimă iubirea divinității față de oameni, iubirea stăpânului față de sclav, dar și iubirea oamenilor față de divinitate; 2. a trata cu afecțiune/cu gingășie un oaspete; 3. într-un cuplu, exprimă afecțiunea izvorâtă dintr-o pasiune, iubitului pentru iubită, soțului pentru soție; 4. a săruta (pe buze, capul, mâinile etc.); 5. despre lucruri și obiecte; 6. despre abstracțiuni, liniștea, pacea, răzbunarea etc.; 7. exprimă rugămintea, cererea.

3. غ̇ $\rho \alpha ́ \omega, ~ \check{\varepsilon} \rho \omega \varsigma$

În cosmogoniile prefilosofice Eros era o forță personificată, spre exemplu, în cosmogoniile orfice el unește toate personificările, cum ar fi Noaptea, Haosul, Pământul, Cerul etc. (Aristotel, Metafizica), și astfel se naște neamul zeilor nemuritori. Conform relatării lui Proclos, când Zeus vrea să creeze ceva, ia chipul lui Eros. Prin urmare, Eros este o formă motrice, plăsmuită după un model 
sexual, prezentă în vechile cosmogonii ${ }^{32}$. De aici, ca verb, are sensul de atracție pasională pentru cineva, de unire și apoi de procreare. Un alt sens al lui $\dot{\varepsilon} \rho \alpha ́ c \omega$ este cel de a dori ceva cu ardoare (ex. o conducere, o funcție în stat, izbânda într-o luptă) sau de a iubi cu înflăcărare (ex. patria).

La Sfinţii Părinţi, prin acest verb se exprimă iubirea lui Dumnezeu față de creație, iubirea lui Hristos față de sufletele neprihănite; iubirea oamenilor față de Dumnezeu; iubirea omului față de lucrurile spirituale; dragostea pervertită a diavolului.

\section{4. $\sigma \tau \dot{\varepsilon} \rho \gamma \omega$}

Se folosește mai mult pentru iubirea familială dintre soți, frați, rude etc. Are sensul de a iubi, a fi afectiv față de cineva. Afectivitatea părinților față de copii, dintre prieteni, a celor conduși față de un conducător, a zeităților tutelare față de casnici, a câinilor față de stăpâni. În ce privește iubirea conjugală, acest termen nu se folosește deloc sau rareori, cum ar fi iubirea dintre soți, dintre frați și surori.

\section{Bibliografie}

1. *** Biblia sau Sfânta Scriptură, tipărită sub îndrumarea şi cu purtarea de grijă a Preafericitului Părinte Teoctist, Patriarhul Bisericii Ortodoxe Române, Bucureşti, Edit. Institului Biblic şi de Misiune al Bisericii Ortodoxe Române, 2006.

2. *** Noul Testament, Evanghelia după Marcu, ediţie bilingvă, introducere, traducere, comentariu şi note patristice de Cristian Bădiliţă, prefaţă de Theodor Paleologu, Bucureşti, Edit. Curtea Veche, 2009.

3. Baştovoi, Savatie, Teama de a vorbi celui iubit, în Orthografiti, anul IV, nr. 17, ianuarie 2011.

4. Bria, Ion, Dogma Sfintei Treimi, în Studii Teologice, seria a II-a, anul XLIII, nr. 3, mai-iunie, 1991.

32 Francis E. Peters, Termenii filosofiei grecești, trad. Drăgan Stoianovici, București, Edit. Humanitas, 1993, p. 97. 
5. Carrez, Maurice, Morel,.François, Dicţionar grec-român al Noului Testament, trad. de Gheorghe Badea, Bucureşti, Societatea Biblică Interconfesională din România, 1999.

6. Cuviosul Paisie Aghioritul, Cuvinte duhovniceşti, vol. II: Viaţa de familie, trad. de Ştefan Nuţescu, Bucureşti, Edit. Evanghelismos, 2003.

7. Felmy, Karl Christian, Dogmatica experienţei ecleziale, înnoirea teologiei ortodoxe contemporane, Sibiu, Editura Deisis, 1999.

8. ftp://ftp.logos.md/Biblioteca/_Colectie_RO/Dumitru_Staniloae_Comu nitate prin iubire.pdf (accesat la data de 13.04. 2016).

9. Georgescu, Constantin, Georgescu, Simona, Georgescu, Theodor, Dicționar grec-român, vol. I, București, Edit. Nemira, 2015.

10. Himcinschi, Mihai, Doctrina trinitară ca fundament misionar, Relaţia Duhului Sfânt cu Tatăl şi cu Fiul în teologia răsăriteană şi apuseană. Implicaţiile doctrinare şi spirituale ale acesteia, Alba Iulia, Edit. Reîntregirea, 2004.

11. Liddell, Henry George, and Scott, Robert, A Greek-English Lexicon, revised and augmented throughout by Sir Henry Stuart Jones with the assistance of Roderick McKenzie, and with the cooperation of many scholars, With a revised supplement, Oxford, Clarendon Press, 1996.

12. Loichiţa, Vasile, Perihoreza si enipostasia în Dogmatică, în Ortodoxia, anul X, nr. 1, ianuarie-martie, 1958.

13. Lossky, Vladimir, Teologia mistică a Bisericii de Răsărit, Bucureşti, Edit. Bonifaciu, 1998.

14. Moltmann, Jurgen, Treimea şi Împărăţia lui Dumnezeu, Alba Iulia, Edit. Reîntregirea, 2007.

15. Munteanu, Daniel, Pe urmele iubirii - contribuţii trinitare la o cultură a comunităţii sfinţitoare, Târgovişte, Edit. Bibliotheca, 2013.

16. Nestle-Aland, Novum Testamentul Graece, post Eberhard Nestle et Erwin Nestle, communiter ediderunt Kurt Aland, Matthew Black, Carlo M. Martini, Bruce M. Metzger, Allen Wikgren, apparatum criticum recensuerunt et editionem novis curis elaboraverunt Kurt Aland et Barbara Aland, una cum Instituto studiorum textus Novi Testamenti Monasteriensi (Westphalia), Stuttgart, Deutsche Bibelgesellschaft, 1979.

17. Nicolescu, Costion, Miza pe prietenie, în Orthografiti, anul 1, nr. 2/decembrie 2008.

18. Nifon Ploieşteanul, vicar patriarhal, Sfânta Treime şi Comuniunea, în Ortodoxia, nr. 3, iulie-septembrie, 2005. 
19. Peters, Francis E. Termenii filozofiei grecești, trad. Drăgan Stoianovici, București, Edit. Humanitas, 1993.

20. Popescu, Dumitru şi Costache, Doru, Introducere în Teologia Dogmatică, Bucureşti, Edit. Libra, 1997.

21. Remete, George, Fiinţa şi credinţa, vol. 1: Ideea de fiinţă, Bucureşti, Edit. Academiei Române, 2012.

22. Stăniloae, Dumitru, Teologie Dogmatică Ortodoxă, vol. I, Bucureşti, Edit. Institutului Biblic și de Misiune al Bisericii Ortodoxe Române, 1996.

23. Stăniloae, Dumitru, Sfânta Treime sau la început a fost iubirea, București, Edit. Institutului Biblic și de Misiune al Bisericii Ortodoxe Române, 2005. 